Research Service and a member of the study group, says that the competitive grants programme will also be helped by the appointment of a full-time director who will report directly to Bentley. (This plan has provoked concern that the job was going to a career bureaucrat; Kinney says that a career employee will serve on an "interim basis" only until an outside and well-qualified director is chosen.) Directors of the competitive grants programme have previously been on part-time leave from their universities; Kinney say's "one of the reasons that competitive grants have not expanded is that there hasn't been a full-time leader" in a position to lobby for it.

Another participant in the White House study, Lowell Lewis, director of the University of California's agricultural experiment stations, states another reason why the time may be ripe for a boost in competitive funding is the mood of Congress and the Administration. "I think we've heard the message clearly that we're not going to get across-the-board increases

\title{
Plutonium reprocessing
}

\section{Fast breeder development}

Spent fast breeder fuel - a mixture of plutonium and uranium oxides and a variety of active fission products - has been reprocessed into new fuel elements at Dounreay, Scotland, with 99.6 per cent efficienty, the United Kingdom Atomic Energy Authority announced last week. The efficiency (the ratio of plutonium leaving fuel fabrication to the plutonium introduced to the reprocessing plant) is crucial to the operation of a fast breeder fuel cycle and - until the Dounreay result - it had been expected to be only 96 per cent at best. Thus Dounreay has reduced potential plutonium fuel cycle losses from an expected 4 per cent to 0.4 per cent.

The figure is not only important for fast breeders in general - it might also be expected to increase Britain's chances of arranging international collaboration (and cost sharing) in the next stage of fast breeder development. France, for example, is leading the world in the construction of the first commercial scale $(1,200 \mathrm{MWe}$ ) breeder, Superphénix (which should go critical in mid-1984 and feed power to the grid by the end of that year). But France is at least three years behind the United Kingdom in fast fuel reprocessing technology.

Could Britain use its reprocessing success as a bargaining card? Sources at the Commissariat à l'Energie Atomique (CEA) think not. According to CEA, 90 per cent of the Superphenix core already comes through reprocessing the fuel of Phenix, its $250 \mathrm{MWe}$ predecessor. But this has been achieved through a patchwork of inefficient processes both at La Hague (the commercial reprocessing centre near Cherbourg) and at Marcoule, a CEA research and production centre on the Rhône.

The largest French fast fuel reprocessing plant - at Marcoule - can handle two tonnes of spent fuel a year, only a quarter of the amount that can be handled at Dounreay. Moreover, efficiency at Marcoule is certainly lower than at Dounreay, although CEA sources express themselves "satisfied", allowing for the fact that the plant is old.

Marcoule is being upgraded, and will be able to handle 5-6 tonnes of fast fuel a year by 1984 . But this in turn is only one quarter of the expected reprocessing needs of Superphénix. Excess spent Superphénix fuel is to be stored in cooling ponds, awaiting the construction of a full scale commercial fast fuel reprocessing plant. To be economic, according to CEA plans, this plant would have to handle the output of up to eight breeders of the size of Superphénix, and have a throughput of up to 170 tonnes a year - a more than twentyfold scale-up of even the Dounreay plant. But, so far, French chemical reprocessing technology has been poor La Hague, for example, has been working well below design capacity because of clogging and other problems.

French sources say, however, that the La Hague hold-ups have been "good experience", and that new plants - such as the upgraded Marcoule - will function well. A light water fuel reprocessing plant built by the French at Tokaimura in Japan is said to be operating efficiently.

Thus the French do not see the Dounreay success as an entry ticket to French reactor technology - particularly as Phénix appears, on the face of it, to have been such a success in comparison with the Dounreay prototype fast reactor (PFR). The two reactors are of the same scale $(250 \mathrm{MWe})$ and vintage (1973). In recent years, PFR has shown a load factor, or proportion of electrical power output to the maximum theoretically possible, of only 20 per cent (in fact just 14 per cent in 1981-82). (By comparison, the world average for pressurized water (thermal) power reactors is about 60 per cent.) But Phénix has recently shown a load factor of around 70-80 per cent.

According to officials at Dounreay, the difference is that the Phénix stainless steel sodium-water heat exchangers, which are subject to leaks, are modular and can be changed quickly. But the cost of such changes would be uneconomic for a commercial reactor. PFR does not have modular exchangers, and so is out of action longer when a leak occurs. Superphénix. however, as a prototype commercial reactor, does not have modular exchangers, and this is leading to some fluttering hearts in France, say Dounreay scientists. in formula funds", he says; a more focused programme - such as competitive grants for basic research - is much more likely to be viewed with favour. Even allowing for the importance of formula funds to those in the land-grant system (and Lewis, like many others, vehemently defends the formula funds as essential to the research that every state needs to conduct on local agricultural problems), these budgetary facts may help to soften resistance to an expanded competitive programme.

Stephen Budiansky

\section{Blow for EISCAT}

The European Incoherent Scatter Facility (EISCAT), opened with much fanfare in August 1981 to probe the Arctic ionosphere, is off the air: a valve has blown. But this valve, a klystron, is 4 metres long and costs $\$ 200,000$.

Luckily, the EISCAT planners had a spare, now being put in place. According to EISCAT director Dr Murray Baron, speaking from Tromso, Norway, the cause of the original valve failure will not be known until it has been disassembled by its manufacturers, Varian Associates of California. He does not blame design error, although such problems led to a three-year delay in the start-up of the facility.

Varian had guaranteed the klystron for 1,000 hours of operation or a year of service; this valve had operated for 3,000 hours when it failed at the end of August, and Baron had expected another couple of thousand hours from it. Although the EISCAT committee has set aside a contingency fund to buy new or reconditioned klystrons every two or three years, this failure after just over a year would cause financial problems if it were repeated. Besides which if the spare valve were to fail, it would be seven to nine months before Varian could produce another, leaving EISCAT without transmitters and thus data. EISCAT has two transmitting systems, one in the UHF (933 MHz), whose klystron has failed, and one in the VHF (224 MHz) which is not yet delivered. The fear is that the fault may be in the equipment, not the valve, in which case the spare would also blow.

Otherwise, EISCAT seems to have been a success. Its three-week summer campaign this year involved rocket flights and television observations in parallel with EISCAT measurements and is said to have given interesting data on aurorae, sporadic E-layers and lowionospheric spectra.

EISCAT is an international collaboration between West Germany, France, the United Kingdom (each contributing 25 per cent of capital and running costs), Sweden and Norway (10 per cent) and Finland ( 5 per cent). The original capital cost was $£ 13$ million.

Robert Walgate 